\title{
PHENOTYPIC AND GENOTYPIC IDENTIFICATION OF FLOUROQUINOLONES RESISTANT ESCHERICHIA COLI ISOLATED FROM DISEASED CHICKEN IN SUEZ CANAL DISTRICT
}

\author{
Dalia A. El-Shazly ${ }^{1}$, Soad A. Nasef ${ }^{2}$, Fadwa Fathy $M^{3}$. \\ ${ }^{1}$ Department of Pharmacology, National Laboratory for Quality Control on Poultry \\ production (NLQP), Animal Health Research Institute (AHRI), Egypt \\ ${ }^{2}$ Department of Poultry diseases, NLQP, AHRI, Egypt. \\ ${ }^{3}$ Department of Bacteriology, NLQP Ismailia branch Lab., AHRI, Egypt.
}

\begin{abstract}
A total of 70 Escherichia coli strains were isolated from samples (liver and heart) collected from diseased chickens $(n=105)$ in about 21 commercial farms located in Suez Canal district of Egypt during May-July 2012. We investigated the susceptibility to Flouroquinolones (Ciprofloxacin, Enrofloxacin and Norfloxacin) and 9 other antibacterials (Gentamicin, Streptomycin, Doxycyclin, Amoxicillin, Ampicillin, Cephazolin, Cephradine, Lincomycin, Florfenicole) by disc diffusion method and measured the MIC of ciprofloxacin and enrofloxacin. Resulted flouroquinolones resistant E.coli isolates were then serotyped, and investigated for the prevalence of plasmidmediated fluoroquinolone resistance (PMQR) genes (qnrA, qnrB, qnrS, aac(6)-Ib-cr, and qepA) by polymerase chain reaction. Among the E.coli isolates, $72.8 \%(51 / 70)$ were resistant to Ciprofloxacin and Enrofloxacin with MIC $\geq 4$ and $\geq 2(\mu \mathrm{g} / \mathrm{ml})$ respectively. These
\end{abstract}


isolates were resistant also to at least 6 other investigated antibacterials in the study for susceptibility/resistance. Among the resistant 51 E.coli strains, 36 (70.5\%) were positive for PMQR genes, 27 (52.9\%) were positive for at least one gene of the qnr genes investigated in the study, 16 (31.37\%) were positive for qnrA, qnrB and qnrS separately, 20 (39.2\%) were positive to aac(6)-Ib-cr, 35 (68.6\%) were positive to qepA, while 4 (7.8\%) harbored all the 5 investigated genes. The resistance of E. coli to flouroquinolones has been increasing in the past twenty years but unfortunately no enough data about isolates harboring PMQR genes in Egypt either in human or poultry field. Further investigations concerning the antimicrobial resistance problem in human and veterinary field in Egypt is recommended as a surveillance program is a must.

Key words: Flouroquinolones resistance, E.coli, qnr, qepA, aac(6')Ib-cr, chickens.

\section{INTRODUCTION}

Antimicrobials are valuable tools to treat clinical disease and to maintain healthy and productive animals. However, the treatment of whole herds and flocks with antimicrobials for disease prevention and growth promotion has become a controversial practice (Van de Boggard, 1999). Sick animals are sometimes treated individually, but often whole flocks or herds of animals are treated at once, including animals that are not ill. In addition, antimicrobials are used in the absence of disease to prevent diseases during times when animals may be susceptible to infections. This practice is very common in countries where infections 
caused by enteric pathogens are severe on poultry farms. Such misuse and/or inappropriate usage increases the likelihood of selecting for organisms that are resistant to the antibiotic. Of particular concern is the emergence of resistance to frontline antimicrobials, such as the fluoroquinolones, which because of their low toxicity and relatively broad-spectrum coverage are extremely valuable for treating human infections (Livermore et al., 2002).

It was stated by well established evidence that antibiotics can lead to the emergence and dissemination of resistant $E$. coli which can then be passed into people via food or direct contact with infected animals. These resistant microbes may function as a potential source in the transportation of antimicrobial resistance to human pathogens (Schroeder et al. 2002).

Unfortunately, data on the prevalence of antimicrobial-resistant veterinary pathogens are sparse, particularly in developing countries where antimicrobials are overused in veterinary medicine and food animals (Ban, 2001). Data on the prevalence of antimicrobial-resistant veterinary pathogens are needed for science-based risk assessments focusing on the relative risks concerning use of antimicrobials in animal husbandry (Yang et al., 2004).

The first quinolone, nalidixic acid (possessing a naphthyridone core), was introduced into clinical use in 1962 (Ball, 2000). In the mid1980s, ciprofloxacin, a fluoroquinolone (with a quinolone core) that had a wider spectrum of in vitro antibacterial activity, particularly against 
gram-negative bacteria, first became available clinically. Since then, newer agents with increased antimicrobial activity against gram-positive pathogens have been developed, but the activity of ciprofloxacin against gram-negative pathogens has been largely unsurpassed (Hooper, 2005). In the decades that have elapsed since the introduction of fluoroquinolones, resistance of the Enterobacteriaceae to these agents has become common, widespread, and generally nonclonal. (Colodner et al., 2001).

It is known that there are at least two mechanisms of resistance to these synthetic antimicrobial agents. The most common mechanism is mutational alteration in the so-called quinolone resistance-determining regions of the drug targets (Hawkey, 2003). The second is the reduction of fluoroquinolone accumulation by active export of the drugs via over expression of chromosomal efflux pumps either alone (Poole, 2005), or associated with decreased production or qualitative alteration of outer membrane porins (Ruiz, 2003). Recently, three additional plasmidmediated low-level resistance mechanisms have been reported: the qnr proteins that protect type II topoisomerases from quinolones (MartinezMartìnez et al., 1998; Robicsek et al., 2006a); aac(6')-Ib-cr, a variant aminoglycoside acetyltransferase that modifies ciprofloxacin (Robicsek et al., 2006b); and a plasmid-mediated efflux pump, qepA (Yamane et al., 2007).

Although normally commensal in nature, certain strains of Escherichia coli are associated with a variety of infections in humans and animals (Bertschinger, 1999). In chickens they may cause infections 
of the respiratory tract and soft tissues, resulting in colibacillosis, air sacculitis, and cellulitis (Gross, 1991). Colibacillosis in poultry farms is usually primary or a secondary infection with viral diseases. The morbidity and mortality are approximately $25 \%$ and $5 \%$, respectively. Poultry farms often use ciprofloxacin or different other antimicrobials to treat infected chicken flocks $(X \boldsymbol{u}, 2001)$.

Aim of work: The poultry reservoir of plasmid-mediated quinolone resistance (PMQR) is still controversial and little information is available on the prevalence of these resistance determinants in developing countries. The aim of this study was to identify, characterize and investigate prevalence of the PMQR in a collection of clinical multiresistant Escherichia coli isolated from diseased chickens with failure of treatment, collected in May-July 2012, in Egypt.

\section{MATERIALS AND METHODS}

Collection of samples: Tissues were collected aseptically according to clinical findings and post mortem examinations of diseased chickens suspected with colibacillosis with no response to antibiotic treatment and exhibiting perihepatitis, pericarditis, airsaculitis and pneumonia. A total of 105 samples (liver, heart) were aseptically collected from 21 different commercial broilers farms distributed in Ismailia, Port Said, Suez and North Sinai in the period from May to July 2012. All samples were directly transported to the laboratory and processed as soon as possible. 
Isolation and Identification: Was done according to Koneman et al. (1992). The collected and prepared samples in were enriched in Buffer Pepton Water (BPW) (Lab, UK) by incubation at $37^{\circ} \mathrm{C}$ for $18-24$ hours. After enrichment, a loopful from the incubated broth was streaked directly onto Eosin- Methylene -Blue Agar, EMB (Lab, UK) and incubated at $37^{\circ} \mathrm{C}$ for $18-24$ hours. Colonies producing metallic sheen were subjected for further biochemical procedures as using Gram's staining, detection of motility, oxidase test, indole test, methyl-red test, Voges-Proskauer test, citrate utilization test, urea hydrolysis test, sugar fermentation (glucose, lactose, sucrose, mannital and salicin), $\mathrm{H}_{2} \mathrm{~S}$ production and gelatine liquefaction.

Antibiogram: All isolated E.coli strains (n=70) were tested for susceptibility to different antimicrobials; Ciprofloxacin $(5 \mu \mathrm{g}$, HiMedia, India), Enrofloxacin (5 $\mathrm{g}$, HiMedia, India)), Norfloxacin (10 $\mu \mathrm{g}$, HiMedia, India), Gentamicin (10 $\mu \mathrm{g}$, HiMedia, India), Ampicillin (10 $\mu \mathrm{g}$, HiMedia, India), Amoxicillin (25 $\mu \mathrm{g}$, HiMedia, India), Florfenicole (30 $\mu \mathrm{g}$, HiMedia, India), Cephradine (30 $\mu \mathrm{g}$, Oxoid, UK), Cephazoline (30 $\mu \mathrm{g}$, Oxoid, UK), Lincomycin (2 $\mu \mathrm{g}$, HiMedia, India), Streptomycin (10 $\mu g$, HiMedia, India) and Doxycycline (10 $\mu \mathrm{g}$, HiMedia, India) by the Disc Diffusion Method on Mueller Hinton Plates (Lab, UK) according to NCCLS (2002). The Minimum Inhibitory Concentration (MIC) of Ciprofloxacin and Enrofloxacin were measured using Broth Macrodilution Method for all E. coli isolates outlined by NCCLS (2002) with Mueller-Hinton broth (Lab, UK). All susceptibility results were interpreted according to the NCCLS interpretive standards (2007). 
Isolates showing MIC $\geq 4(\mu \mathrm{g} / \mathrm{ml})$ for ciprofloxacin and $\geq 2$ for Enrofloxacin (Bayer recommendations) were considered resistant. E. coli ATCC 25922 was used as quality control organism in antimicrobial susceptibility experiments.

Serotyping: Serotyping of the resistant E.coli isolates was done at the Bacteriology Unit in Reference Lab. for veterinary Quality control on Poultry production (RLQP)-Dokki, Egypt (accredited for Iso 17025). E. coli strains were biochemically confirmed and submitted to slide agglutination tests using polyvalent and monovalent antisera against serogroups and serotypes O26, O25, O103, O111, O78, O114, O145, O185, O91, O86, O44 and O86. Commercially available antisera were used.

Isolation and identification of resistance genes by PCR: All resistant E.coli isolates ( $\mathrm{n}=51)$ were screened by PCR amplification for the transferable quinolone resistance determinants qnrA, qnrB, qnrS (Robicsek et al., 2006c), aac-(6')-Ib-cr (Lunn et al., 2010) and qepA (Cattoir, 2008) in Biotechnology Unit, RLQP (accredited for Iso. 17025). Bacterial DNA was extracted using QIAamp DNA Mini Kit (Qiagen, Germany, Cat.no. 51304). PCR was carried out in a final volume of $25 \mu \mathrm{l}$ containing $6 \mu \mathrm{l}$ template DNA, $1 \mu \mathrm{l}$ (20 Pmol) of each primer, $12.5 \mu \mathrm{l}$ of EmeraldAmp® MAX (Germany, Cat.no. RR320A) and $4.5 \mu \mathrm{ddH} 2 \mathrm{O}$. All samples were subjected to primary denaturation and Taq polymerase activation at $95 \square \mathrm{C}$ for $10 \mathrm{~min}$. and final extension cycle at $72 \square \mathrm{C}$ for $10 \mathrm{~min}$. The primers, cycling conditions and product sizes were summarized in Table (1). 
Dalia A. El-Shazly et., al.

Table (1): Primers and cycling conditions of the genes PMQR genes

\begin{tabular}{|c|c|c|c|c|c|}
\hline Gene & Primers & $\begin{array}{c}\text { Amplified } \\
\text { segment (bp) }\end{array}$ & \begin{tabular}{|c|} 
Secondary \\
denaturation
\end{tabular} & Annealing & Extension \\
\hline \multirow{2}{*}{ qepA } & 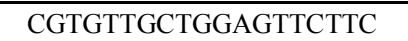 & \multirow{2}{*}{403} & \multirow{2}{*}{$\begin{array}{c}94^{\circ} \mathrm{C} \\
45 \mathrm{sec} .\end{array}$} & \multirow{2}{*}{$\begin{array}{l}50^{\circ} \mathrm{C} \\
45 \mathrm{sec}\end{array}$} & \multirow{2}{*}{$\begin{array}{l}72^{\circ} \mathrm{C} \\
45 \mathrm{sec}\end{array}$} \\
\hline & CTGCAGGTACTGCGTCATG & & & & \\
\hline \multirow{2}{*}{$q n r A$} & ATTTCTCACGCCAGGATTTG & \multirow{2}{*}{516} & \multirow{6}{*}{$\begin{array}{l}94^{\circ} \mathrm{C} \\
45 \mathrm{sec} .\end{array}$} & \multirow{6}{*}{$\begin{array}{l}53^{\circ} \mathrm{C} \\
45 \mathrm{sec}\end{array}$} & \multirow{6}{*}{$\begin{array}{l}72^{\circ} \mathrm{C} \\
60 \mathrm{sec}\end{array}$} \\
\hline & GATCGGCAAAGGTTAGGTCA & & & & \\
\hline \multirow{2}{*}{$q n r B$} & GATCGTGAAAGCCAGAAAGG & \multirow{2}{*}{469} & & & \\
\hline & ACGATGCCTGGTAGTTGTCC & & & & \\
\hline \multirow{2}{*}{$q n r S$} & ACGACATTCGTCAACTGCAA & \multirow{2}{*}{417} & & & \\
\hline & TAAATTGGCACCCTGTAGGC & & & & \\
\hline \multirow{2}{*}{$a a c\left(6^{\prime}\right)-I b-c r$} & CCCGCTTTCTCGTAGCA & \multirow{2}{*}{113} & \multirow{2}{*}{$\begin{array}{c}94^{\circ} \mathrm{C} \\
30 \mathrm{sec} .\end{array}$} & \multirow{2}{*}{$\begin{array}{l}52^{\circ} \mathrm{C} \\
30 \mathrm{sec}\end{array}$} & \multirow{2}{*}{$\begin{array}{l}72^{\circ} \mathrm{C} \\
30 \mathrm{sec}\end{array}$} \\
\hline & TTAGGCATCACTGCGTCTTC & & & & \\
\hline
\end{tabular}

\section{RESULTS}

The number and percentage of resistant E.coli isolates in relation to the geographic area and time of sample collection were summarized in Table (2).

Table (2): Sample collection and E.coli isolation in relation to geographic area and time of collection

\begin{tabular}{|c|c|c|c|c|c|c|c|c|}
\hline & \multicolumn{4}{|c|}{ Area } & \multicolumn{3}{|c|}{ Time } & \multirow{2}{*}{ Total } \\
\hline & Ismailia & Port Said & Suez & $\begin{array}{l}\text { North } \\
\text { Sinai }\end{array}$ & May & June & July & \\
\hline No. of farms & 15 & 1 & 2 & 3 & 7 & 5 & 9 & 21 \\
\hline No. of samples & 75 & 5 & 10 & 15 & 35 & 25 & 45 & 105 \\
\hline No. of Isolated E.coli & 53 & 4 & 2 & 11 & 20 & 20 & 30 & 70 \\
\hline No. of resistant E.coli & 36 & 4 & 2 & 9 & 18 & 13 & 20 & 51 \\
\hline Percentage of resistant E.coli & 67.9 & 100 & 100 & 81.8 & 90 & 65 & 66.6 & 72.8 \\
\hline
\end{tabular}

Antimicrobial resistance pattern: The 70 E.coli isolates showed a susceptibility/resistance pattern against ciprofloxacin, enrofloxacin, norfloxacin as Flouroquinolones in addition to different other antimicrobial types, summarized in Table (3). 
Phenotypic And Genotypic Identification Of flouroquinolones ...

Table (3): The susceptibility and resistance pattern of E.coli Isolates against flouroquinolones and other antimicrobials by Disc Diffusion Method

\begin{tabular}{|c||c||c||c||c||c|c|c||c||c||c||c||c||}
\hline No. & Cip5 & Enr5 & Nor10 & G10 & FFC30 & Amp10 & Am25 & S10 & Dox10 & L2 & CE30 & KZ30 \\
\hline \hline S & 2 & 2 & 0 & 24 & 0 & 1 & 1 & 9 & 0 & 0 & 0 & 0 \\
\hline I & 17 & 6 & 11 & 6 & 0 & 0 & 0 & 5 & 52 & 0 & 0 & 0 \\
\hline R & 51 & 62 & 59 & 40 & 70 & 69 & 69 & 56 & 18 & 70 & 70 & 70 \\
\hline
\end{tabular}

Cip5:ciprofloxacin $5 \mu \mathrm{g}$, FFC30:florfenicole 30 $\mu \mathrm{g}$ Dox10:doxycyclin $10 \mu \mathrm{g}$,

S: susceptible,
Enr5:enrofloxacin 5 $5 \mathrm{~g}$,

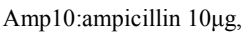

L2:lincomycin $2 \mu \mathrm{g}$

I: intermediate,
Nor10:norfoxacin $10 \mu \mathrm{g}$, Am25:amoxicillin 25 $\mu \mathrm{g}$, CE30:cepheradine 30 $\mu \mathrm{g}$, R: resistant (according to NCCLS, 2007)
G10:gentamicin $10 \mu \mathrm{g}$, S10:streptomycin $10 \mu \mathrm{g}$, KZ30: cephrazoline $30 \mu \mathrm{g}$.

Two E.coli isolates were susceptible to both ciprofloxacin and enrofloxacin with MIC of $0.312(\mu \mathrm{g} / \mathrm{ml})$ and also to gentamicin, but resistant to all other antimicrobials used in the study. 51 E.coli isolates (72.8\%) were found resistant to ciprofloxacin and enrofloxacin with MIC range of 4-32 and 8-32 $(\mu \mathrm{g} / \mathrm{ml})$ respectively in addition to at least 6 other antimicrobials.

Serotyping: E.coli serotypes of resistant isolates were summarized in Table (4).

Table (4): different serotypes of resistant E.coli isolates

\begin{tabular}{|c|c|c|c|c|c|c|c|c|c|c|c|c|c|}
\hline \multirow[b]{2}{*}{ 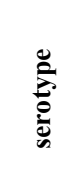 } & \multicolumn{5}{|c|}{ Poly I } & \multicolumn{2}{|c|}{ Poly II } & \multicolumn{4}{|c|}{ Poly III } & \multirow[b]{2}{*}{ 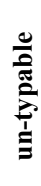 } & \multirow[b]{2}{*}{$\begin{array}{c}\text { A } \\
\text { typical } \\
\text { E.coli }\end{array}$} \\
\hline & 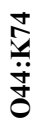 & $\frac{\frac{1}{\ddot{\infty}}}{\infty}$ & 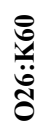 & $\frac{\dot{y}}{\ddot{\sigma}}$ & $\begin{array}{l}\frac{\partial}{\partial} \\
\ddot{\dot{\Xi}} \\
\overline{0}\end{array}$ & $\begin{array}{l}\bar{\square} \\
\ddot{0} \\
0 \\
0\end{array}$ & 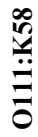 & $\frac{\stackrel{d}{\ddot{c}}}{\frac{\ddot{g}}{0}}$ & $\begin{array}{l}\stackrel{8}{0} \\
\stackrel{0}{0} \\
\stackrel{0}{0}\end{array}$ & $\frac{\ddot{\tilde{\theta}}}{\ddot{\theta}}$ & $\begin{array}{l}\overline{\bar{z}} \\
\ddot{\ddot{n}} \\
0\end{array}$ & & \\
\hline 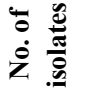 & 4 & 6 & 5 & 2 & 5 & 3 & 3 & 2 & 3 & 4 & 2 & 11 & 1 \\
\hline
\end{tabular}

Kafrelsheikh Vet. Med. J. Vol. 12 No. 1 (2014) 
Screening for the Flouroquinolones resistance genes: Among the total of 51 resistant isolates, PMQR determinants were present in 36 (70.5\%), with qnr, aac(6 $\left.6^{\prime}\right)$-Ib-cr, and qepA being detected alone or in combination in $27(52.9 \%), 20(39.2 \%)$, and $35(68.6 \%)$ strains, respectively. Among the twenty seven strains positive for qnr genes, 16 were positive for qnrA, qnrB and qnrS separately. Four strains (7.8\%) were positive for all investigated genes while 4 other strains harboured qepA alone (the only strains that harboured only one gene). 20 strains carried both aac $\left(6^{\prime}\right)$-Ib-cr and qepA coexisted. Detailed information on these PMQR determinant-positive isolates is given in Table (5).

Table (5): Prevalence of PMQR Genes among Escherichia coli resistant Isolates $(\mathrm{n}=51)$

\begin{tabular}{|c|c|c|c|c|c|c|c|c|}
\hline & \multicolumn{7}{|c|}{ Positive for PMQR Genes } & \multirow[b]{2}{*}{$\begin{array}{l}\text { Negative for } \\
\text { PMQR genes }\end{array}$} \\
\hline & 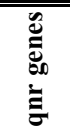 & $\overleftrightarrow{\leftrightarrows}$ & 竎 & $\stackrel{\mathscr{E}}{\Xi}$ & 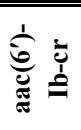 & $\begin{array}{l}\overleftrightarrow{4} \\
\frac{0}{\sigma}\end{array}$ & 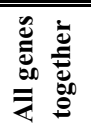 & \\
\hline No. of resistant strains & 27 & 16 & 16 & 16 & 20 & 35 & 4 & 15 \\
\hline percentage of resistant strains & 52.9 & 31.37 & 31.37 & 31.37 & 39.2 & 68.6 & 7.8 & 29.5 \\
\hline MIC range: Ciprofloxacin & $4-32$ & $4-32$ & $4-32$ & $4-32$ & $4-32$ & $4-32$ & $16-32$ & $8-16$ \\
\hline Enrofloxacin & $8-32$ & $8-32$ & $8-32$ & $8-32$ & $8-32$ & $8-32$ & $16-32$ & $8-16$ \\
\hline
\end{tabular}

Lane 1: aac(6')Ib-cr 113 bp

Lane 2: qnrS 417 bp

Lane 3: Marked DNA Molecular Weight

Marker Gel Pilot 100 bp ladder (cat. no. 239035), QIAGEN (USA).

Lane 4: qnrB 469 bp

Lane 5: qnrA 516 bp

Lane 6: qepA 403 bp

Lane 7: Negative control

Agarose Gel Showing Bands of Amplified PCR Products of PMQR Genes of $E$. coli Isolated from diseased chickens

$\overline{\text { Kafrelsheikh Vet. Med. J. Vol. } 12 \text { No. } 1 \text { (2014) }}$

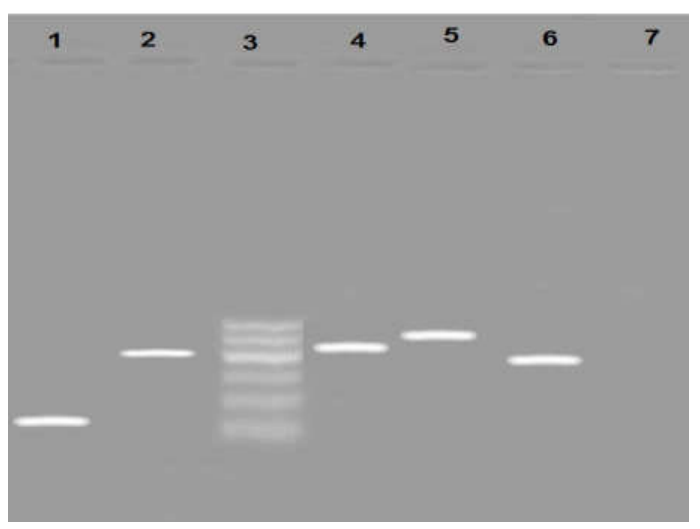




\section{DISSCUSION}

Antibacterial resistance is a global problem especially in developing countries like Egypt. Our investigation took advantage of the repeated and high sounded complains from commercial broilers farms suffering from treatment failure of their flocks and admitting samples to our laboratory for sensitivity test. The emergence of strains showing resistance to several quinolones is a public health concern. Before the early 1990s, clinical isolates of E. coli rarely showed resistance to quinolones. However, since then the frequency of resistance has significantly increased worldwide (Hopkins et al., 2005). In this study, $72.8 \%$ of $E$. coli isolates had high resistance to some flouroquinolones in addition to multiresistance to other antimicrobials. Resistance to 7 quinolone antimicrobial agents was observed in more than $50 \%$ of the E.coli isolates from chickens during 2000-2008 in China by Chen et al. (2011) and considered that prevalence ratio very high.

Different serotypes were identified among resistant E.coli isolates (about 11 serotypes). Despite that avian pathogenic E. coli most commonly belongs to $\mathrm{O} 1, \mathrm{O} 2$, or $\mathrm{O} 78$ and typically possesses virulence factors (Mellata et al., 2003), we detected other serotypes of mostly O185, O44, O114, O26, O103. These findings agree with those found by Fatma Yousseff et al. (2008) who isolated also different serotypes of E.coli from layers and broilers in Ismailia, Egypt (O78, O26, O1, O2, O157 and O111) showing multiresistance to danofloxacin, oxytetracycline, ampicillin and amoxicillin and Fatma et al. (2012) who identified about 
6 serotypes of E.coli (O18, O114, O78, O103, O86 and O12) isolated from breeders and broilers poultry farms in Mansoura, Egypt, with evidence of multiresistant $\mathrm{O} 78$ and $\mathrm{O} 114$ to streptomycin, flumequine and nalidexic acid. Mai Kandil et al. (2011) isolated O78:K80, O86:K61 from chicken meat, O26:K60 from mastitic cow while O114:K58 from cow meat from different sources in Egypt. It is interesting to indicate that O86:K61 identified in current study (3/51) was isolated and identified also from urine of haemolytic urimic humans in Egypt (12/110) by Osman et al. (2012).

Our findings of $36(70.5 \%)$ resistant E.coli strains from diseased chickens positive for $\mathrm{PMQR}$ genes in comparison to $\mathbf{M a}$ et al. (2009) findings; of 34.7 and $66.7 \%$ from food producing animals and companion animals respectively, were considered high and can be related to the difference in the health status of hosts; as we collected samples from diseased chickens suffering from treatment failure.

Since the first plasmid-mediated quinolone resistance gene qnrA was reported in 1998 (Martìnez-Martinez et al., 1998), three major groups of qnr genes, qnrA, qnrB, and qnrS, have been identified in various enterobacterial species with a wide range of prevalence (Cheung et al., 2005; Jeong et al., 2005; Paauw et al., 2006; Chen et al., 2006; $\boldsymbol{W u}$ et al., 2007). The overall qnr prevalence ranged from $0.2 \%$ to $50 \%$, depending on the strain selection criteria used in each study. In our study the frequency of qur genes (at least one of them) was $52.9 \%$ which is considered high compared to $26.6 \%$ found by Hassan et al. (2012) in ESBL producing E.coli clinical isolates from human in Egypt. 
Lascols et al. (2007), Cesaro et al. (2008) and Kuo et al. (2009) have shown that ciprofloxacin resistance (MIC $\geq 4 \mu \mathrm{g} / \mathrm{ml}$ ) is closely related to the number of topoisomerase mutations in gyrA and parC, and further to the additional harbouring of $q n r$ gene in E. coli strains. Similar results were found in this study that all of the resistant E.coli isolates, harbouring at least one of the 5 genes investigated, resisted ciprofloxacin and enrofloxacin with MIC rang of 4-32 and 8-32 $\mu \mathrm{g} / \mathrm{ml}$ respectively, including also the resistant isolates harbouring no genes (with MIC 8-16 $\mu \mathrm{g} / \mathrm{ml}$ for both ciprofloxacin and enrofoxacin) and suggesting to have a number of topoisomerase mutations in gyrA and ParC.

The aac(6')-Ib gene encodes a common aminoglycoside acetyltransferase responsible for resistance to aminoglycoside antibiotics such as kanamycin, amikacin and tobramycin (Vakulenko and Mobashery, 2003). The aac(6')-Ib-cr is a variant of the aac(6')-Ib gene, in which twelve base pairs at the $5^{\prime}$ end are different, and which harbours mutations at codons 102 (Trp102Arg) and 179 (Asp179Tyr). Consequently, the variant enzyme acetylates ciprofloxacin and norfloxacin, conferring slightly higher MICs with a 2-to 4-fold increase (Robicsek et al., 2006b). This may explain why the resistant E.coli isolates in our study carring aac(6')-Ib-cr were multiresistant to ciprofloxacin, enrofloxacin and gentamicin. The aac $\left(6^{\prime}\right)-\mathrm{Ib}$-cr gene, which is capable of modifying ciprofloxacin and reducing its activity, seems to have recently emerged, but in our study it was even more prevalent than the qnr A or B or S genes with prevalence of $39.2 \%$ which is high compared to $23.3 \%$ found by Hassan et al.(2012) in human 
E.coli clinical isolates from Egypt, and 1\% resulted by Gosling et al. (2012) in ciprofloxacin resistant E.coli isolates from Turkey in England, when both $q n r A$ and $a a c\left(6^{\prime}\right)-I b-c r$ are present in the same cell, the level of resistance is increased fourfold more than that conferred by $q n r A$ alone (Robicsek et al.,2006b). We could not confirm that genetic combination effect on MIC from our findings as the same MIC range was recorded for qnr genes found separately or combined with aac $\left(6^{\prime}\right)$ Ib-cr $(4-32 \mu \mathrm{g} / \mathrm{ml})$.

The recently identified qepA gene was detected in E. coli isolates from pigs (Liu et al., 2008), chickens (Wu et al., 2009), companion and food producing animals (Ma et al. , 2009) and human (Xi et al., 2009) in China, and in various Gram-negative bacteria isolated in other countries of Asia (Chen et al., 2006, Yamane et al., 2007), Europe (Bogaerts et al., 2007; Périchon et al., 2007) and E.coli isolated from human in Egypt (Ghada Helaly et al., 2010). Their prevalence findings ranged from $0.2-15.8 \%$. Our finding of the prevalence of qepA gene $(68.6 \%)$ in resistant E. coli isolates was considered high in comparison to other countries. Unfortunately, due to the low data available about the flouroquinolone resistance in E.coli isolated from Egypt, we could not confirm our results in resistant E.coli isolated from chickens as Ghada Helay et al. (2010) and Hassan et al. (2012) detected only qepA gene in only $4.4 \%(2 / 45)$ and $6.6 \%(2 / 30)$ respectively of human flouroquinolones resistant E.coli. 
In conclusion, the results obtained in this study showed that flouroquinolones resistance and PMQR determinants were highly prevalent in E.coli strains from diseased chickens in Egypt and call for a national wide surveillance program to monitor microbial trends and antimicrobial resistance patterns in both medical practice and animal husbandry.

Acknowledgement: We thank Prof. Dr. Mohamed K. Morsi, Professor of Poultry diseases and Head of Ismailia Branch Laboratory, NLQP for the facilities he provided during samples collection.

\section{REFERENCES}

- Ball, P. (2000): Quinolone generations: natural history or natural selection? J. Antimicrob. Chemother. 46(Suppl. T1):17-24.

- Ban, F. (2001): Food safety of animal origin and surveillance for drug residues in animal products. Henan Anim. Sci. Vet. Med. 22:5-7.

- Bertschinger, H. U. (1999): Postweaning E. coli diarrhea and edema disease, p. 441-454. In B. E. Straw, S. D'Allaire, W. L. Mengeling, and D. J. Taylor (ed.), Diseases of swine. Iowa State University Press, Ames.

- Bogaerts, P.; Galimand M; Bauraing C; et al. (2007): Emergence of ArmA and RmtB aminoglycoside resistance 16S rRNA methylases in Belgium. J Antimicrob Chemother 59:459-464.

- Cattoir, V.; Poirel, L. and Nordmann, P. (2008): Plasmid-Mediated Quinolone Resistance Pump QepA2 in an Escherichia coli Isolate from France. Antimicrobial Agents and Chemotherapy,p.3801-3804. 
- Cesaro, A.; Bettoni, R.R.; Lascols, C.; Merens, A.; Soussy, C.J.; Cambau, E. (2008): Low selection of topoisomerase mutants from strains of Escherichia coli harbouring plasmid-borne qnr genes. The Journal of Antimicrobial Chemotherapy, 61, 1007-1015.

- Chen, Y.T.; Shu, H.Y.; Li, L.H. et al. (2006): Complete nucleotide sequence of pK245, a 98-kilobase plasmid conferring quinolone resistance and extended-spectrum-b-lactamase activity in a clinical Klebsiella pneumoniae isolate. Antimicrob Agents Chemother 50:3861-3866.

- Chen, X.; Pan, W.; Zhan, W.; Pan, Z.; Gao, S. and Jiao, X. (2011): Quinolone resistance in Escherichia coli and Salmonella spp. isolates from diseased chickens during 1993-2008 in China. African J of Microbio Res Vol. 5(19), pp. 3078-3083.

- Cheung, T.K.; Chu, Y.W.; Chu, M.Y. et al. (2005): Plasmid-mediated resistance to ciprofloxacin and cefotaxime in clinical isolates of Salmonella enterica serotype Enteritidis in Hong Kong. J. Antimicrob Chemother 56:586-589.

- Colodner, R., Y. Keness, B. Chazan, and R. Raz. (2001): Antimicrobial susceptibility of community-acquired uropathogens in northern Israel. Int.J. Antimicrob. Agents 18:89-92.

- Fatma, A.G.; El-Gohary, A.H.; El-Bably, M.A. and Mohamed, A.A.: (2012): In-Vitro Antibiotic Sensitivity of Isolated Strains Of Salmonella And E.coli from Poultry Farms. 7th Int. Sosci. Conf., Mansoura. 
- Fatma M. Yousseff; Mona A. Ahmed and Dalia H. Mansour (2008): Clinical, Pathological and Bacteriological Investigations on Air Sacculitis in Chickens in Ismailia Province (Egypt).

- Journal of Agricultural and Veterinary Sciences, Qassim University, Vol. 1, No. 2, P. 71-79

- Ghada, F.Helaly; Hamida, A.; Nourhan H.F.; Ola Abdelazizi and Ghada H.Ali. (2010): Potential Co-prevalence of Plasmid-Mediated Quinolone Resistance Determinant qepA and 16S rRNA Methylase $r m t B$ among E.coli Clinical Isolates from Alexandria- Egypt. $J$ Egypt Public Health Assoc Vol. 85 No. 5 \& 6

- Gosling, R.J.; Clouting, C. S.; Randall, L. P.; Horton, R. A. and Davies, R. H. (2012): Ciprofloxacin resistance in E. coli isolated from turkeys in Great Britain. Avian Pathology V 41, Issue 1

- Gross, W. B. (1991): Colibacillosis, p. 138-144. In B.W. Calnek (ed.), Diseases of poultry, 9th ed. Iowa State University Press, Ames

- Hassan, W.M.; Hashim, A. and Domany, R.A.A. (2012): Plasmid mediated quinolone resistance determinants qnr, aac(6 )-Ibcr, and qep in ESBL-producing Escherichia coli clinical isolates from Egypt. Indian J for Medical Microbiology 30, 4: 422-447

- Hawkey PM. (2003): Mechanisms of quinolone action and microbial response. J Antimicrob Chemother 51:29-35.

- Hooper, D. C. (2005): Quinolones, p. 451-467. In G. L. Mandell, R. G. Douglas, J. E. Bennett, and R. Dolin (ed.), Mandell, Douglas, and Bennett's principles and practice of infectious diseases, 6th ed. Elsevier/Churchill Livingstone, New York, NY. 
- Hopkins, K.L.; Davies, R.H. and Threlfall, E.J. (2005): Mechanisms of quinolone resistance in $E$. coli and Salmonella: recent developments. Int. J. Antimicrob. Ag., 25: 358-373.

- Jeong, J.Y.; Yoon, H.J.; Kim, E.S. et al. (2005): Detection of qnr in clinical isolates of Escherichia coli from Korea. Antimicrob Agents Chemother 49:2522-2524

- Koneman, E.W., Allen, S.D.; Janda, W.M.; Schreckenberger, C. and Winn, W.C. (1992): Diagnostic Microbiology. J.B. Lippincott company. USA.

- Kuo, H.C.; Chou, C.C.; Tu, C.; Gong, S.R.; Han, C.L.; Liao, J.W.; Chang, S.K. (2009): Characterization of plasmid-mediated quinolone resistance by the qnrS gene in Escherichia coli isolated from healthy chickens and pigs. Veterinarni Medicina, 54 (10): 473-482

- Lascols C.; Robert J.; Cattoir V.; Bebear C.; Cavallo J.D.; Podglajen I.; Ploy M.C.; Bonnet R.; Soussy C.J.; Cambau E. (2007): Type II topoisomerase mutations in clinical isolates of Enterobacter cloacae and other enterobacterial species harbouring the qnrA gene. International Journal of Antimicrobial Agents, 29, 402409.

- Liu, J.H.; Deng, Y.T.; Zeng, Z.L. et al. (2008): Coprevalence of plasmidmediated quinolone resistance determinants QepA, Qnr, and AAC(6')-Ib-cr among 16S rRNA methylase RmtB producing Escherichia coli isolates from pigs. Antimicrob Agents Chemother 52:2992-2993. 
- Livermore, D. M., D. James, M. Reacher, C. Graham, T. Nichols, P. Stephens, A. P. Johnson, and R. C. George. (2002): Trends in fluoroquinolone (ciprofloxacin) resistance in Enterobacteriaceae from bacteremias, England and Wales, 1990-1999. Emerg. Infect. Dis. 8:473-478.

- Lunn, A. D.; Fàbrega, A.; Sànchez-Céspedes, J.; Vila, J. (2010): Prevalence of mechanisms decreasing quinolone-susceptibility among Salmonella spp. clinical isolates. International Microbiology 13:15-20

- Ma, J.; Zeng, Z.; Chen, Z.; Xu, X.; Wang, X.; Deng, Y. et al. (2009): High prevalence of plasmid mediated quinolone resistance determinants $q n r$, $a a c\left(6^{\prime}\right)-I b-c r$, and $q e p A$ among ceftiofur-resistant Enterobacteriaceae isolates from companion and food-producing animals. Antimicrob Agents Chemother. 53:519-24.

- Mai M. Kandil; Gad El-Said, W.A.; Ata S. Nagwa; Galal, H.; Marouf, S.A.; El-Jakee, J. and Elgabry, A. (2011): Diversity of Escherichia coli Outer Membrane Protein. World Applied Sciences Journal 15 (9): 1211-1219

- Martìnez-Martìnez, L, Pascual A, Jacoby GA (1998): Quinolone resistance from a transferable plasmid. Lancet, 351: 797-799.

- Mellata, M., M. Dho-Moulin, C. M. Dozois, I. R. Curtiss, P. K. Brown, P. Arne, A. Bree, C. Desautels, and J. M. Fairbrother (2003): Role of virulence factors in resistance of avian pathogenic Escherichia coli to serum and in pathogenicity. Infect. Immun. 71:536-540. 
- NCCLS: Clinical and Laboratory Standards Institute. Performance Standards for Antimicrobial Susceptibility Testing: Seventeenth Informational Supplement M100-S17. CLSI, Wayne, PA, USA: 2007.

- NCCLS: Performance standards for antimicrobial disk and dilution susceptibility tests for bacteria isolated from animals (2002); approved standard. NCCLS document M31A. Wayne, Pennsylvania: National Committee for Clinical Laboratory Standard.

- Osman,K.M.; Mustafa,A.M.;Elhariri,M.; AbdElhamed, G.S.(2012): Identification of serotypes and virulence markers of Escherichia coli isolated from human stool and urine samples in Egypt. Indian Journal of medical microbiology V 30, Issue 3, P 308-313.

- Paauw, A.; Fluit, A.C.; Verhoef, J. et al. (2006): Enterobacter cloacae outbreak and emergence of quinolone resistance gene in Dutch hospital. Emerg Infect Dis 12:807-812.

- Périchon, A.; Courvalin, P. and Galimand, M. (2007): Transferable resistance to aminoglycosides by methylation of G1405 in 16S rRNA and to hydrophilic fluoroquinolones by QepA-mediated efflux in Escherichia coli. Antimicrob Agents Chemother 51:2464-2469.

- Poole, K. (2005): Efflux-mediated antimicrobial resistance. J Antimicrob Chemother 56:20-25.

- Robicsek, A., Jacoby, G.A., Hooper, D.C. (2006a): The worldwide emergence of plasmid-mediated quinolone resistance. Lancet Infect. Dis., 6:629-640. 
- Robicsek, A.; Strahilevitz, J.; Jacoby, G.A.; Macielag, M.; Abbanat, D.; Park, C.H.; Bush, K. and Hooper, D.C. (2006b): Fluoroquinolone-modifying enzyme: a new adaptation of a common aminoglycoside acetyltransferase. Nat. Med., 12: 83-88.

- Robicsek, A.; Strahilevitz, J.; Sahm, D.F.; Jacoby, G.A. and Hooper, D.C. (2006c): qnr prevalence in ceftazidimeresistant Enterobacteriaceae isolates from the United States. Antimicrobial Agents and Chemotherapy, 50, 2872-2874.

- Ruiz, J. (2003): Mechanisms of resistance to quinolones: target alterations, decreased accumulation and DNA gyrase protection. J Antimicrob Chemother 51:1109-1117.

- Schroeder, C.M.; Zhao, C.; Debroy, C.; Torcolini, J.; Zhao, J. and White, D.G. (2002): Antimicrobial resistance of Escherichia coli 0157:H7 isolated from humans, cattle, swine and food. Applied Environ. Micribio. 68: 576-581

- Van den Bogaard, A. E., and E. E. Stobberingh. (1999): Antibiotic usage in animals: impact on bacterial resistance and public health. Drugs 58:589-607

- Vakulenko, S. B. and Mobashery, S. (2003): Versatility of aminoglycosides and prospects for their future. Clinical Microbiology Reviews, 16, 430-450.

- Wu, J.J.; Ko, W.C.; Tsai, S.H. et al. (2007): Prevalence of plasmidmediated quinoloneresistance determinants QnrA, QnrB, and QnrS among clinical isolates of Enterobacter cloacae in a Taiwanese hospital. Antimicrob Agents Chemother 51:1223-1227. 
- Wu, C.; Wang, Y.; Cao, X.Y. et al. (2009): Emergence of plasmidmediated quinolone resistance genes in Enterobacteriaceae isolated from chickens in China. J Antimicrob Chemother 63:408-411.

- Xi, L.N.; Li, L.; Wu, C.M.; Liu, Y.Q.; Tao, X.Q.; Dai, L.; Qi, Y.H.; Lu, L.M. and Shen, J.Z. (2009): A Survey of Plasmid-Mediated Fluoroquinolone Resistance Genes from Escherichia coli Isolates and Their Dissemination in Shandong, China. Forborne Pathogins and Disease V 00, N 00

- Xu, S. (2001): Actions China needs to take in response to the emergence of antimicrobial resistance. Chinese J. Vet. Drugs 35:39-41.

- Yamane, K.; Wachino, J.; Suzuki, S.; Kimura, K.; Shibata, N.; Kato, H.; Shibayama, K.; Konda, T. and Arakawa, Y. (2007): New plasmid-mediated fluoroquinolone efflux pump, QepA, found in an $E$. coli clinical isolate. Antimicrob. Agents Ch., 51: 3354-3360

- Yang, H.; Chen, S.; White, D.G.; Zhao, S.; McDermott, P.; Walker, R. and Meng, J.(2004): Characterization of MultipleAntimicrobial-Resistant Escherichia coli Isolates from Diseased Chickens and Swine in China . J. Clin. Microbiol. August 2004 vol. 42 no. $83483-3489$. 


\section{التعريف الظاهري والجيني للميكروب القولوني المقاوم للفلوروكينولون المعزول من الدجاج المصاب في منطقة قناة السويس}

داليا عبد الرحمن الثاذلي' سعاد عبد العزيز ناصف ‘ فدوي فتحي محمود؟

$$
\text { ' ' المعمل القومي للرقابة علي الانتاج الداجني _ قسم الفارماكولوجي }
$$

r المعمل القومي للارقابة علي الانتاج الداجني _معل فرعي الاسماعيلية _قسم البكتبريولوجي

تم عزل عدد • V سلالة من الميكروب القولوني من عينات (الكبد و القلب) التي تم جمعها من الدجاج المصاب (عدد = 0. (1) في حو الي |ب مزرعة تجارية تقع في منطقة قناة السويس في مصر

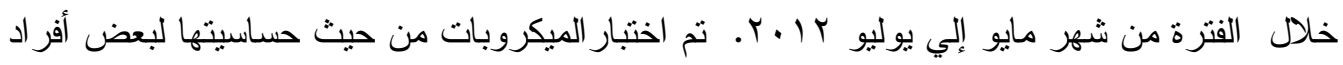
مجموعة الفلوروكينولون (سييروفلوكساسين ، انروفلوكساسين ، نورفلوكساسين) وبعض المضادات الحيويـة الأخـرى (جنتاميسين ، الستربتوميسين ، دوكسي سـايكلين ، أموكسيسيلين ، الأمبيـلين ،سيفازولين، سيفر ادين ، لينكومايسين ، فلورفينيكول) و قياس الثركيز الأدني المثبط للميكروب مـن المضاد البكتيري سييروفلوكساسين و انروفلوكساسين ـ تلي ذلك تصنيف سيرولوجي للمعزو لات التي تم التعرف الظاهري علي مقاومتها للفلوروكينولون ، وكذللك الكثف علي مدي انتشار الجينات (qnrA, qnrB, qnrS, المحملة علي البلازميد و المسئولة عن المقاومـة البكتيريـة للفلوروكينولـون aac(6')-Ib-cr, and qepA)

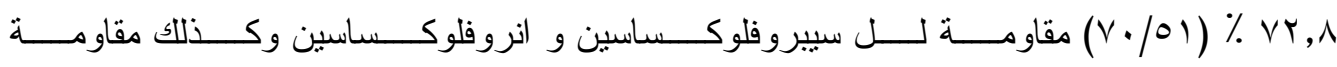


لـ 1 على الأقل من المضادات الحيوية الأخرى قيد الدراسـة ـ بـين المعزو لات المتعددة المقاومـة للمضادات الحيوية و عددها (0 ، كانت ؟ب (0, • ٪ ٪) إيجابية للجينات المحملة علي البلازميد، حيث

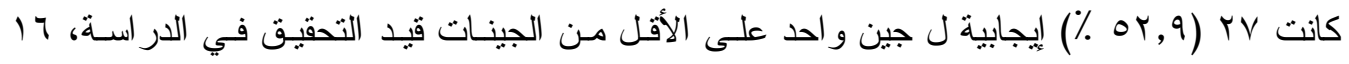

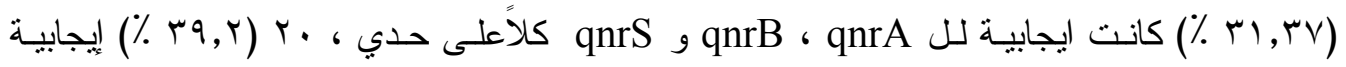

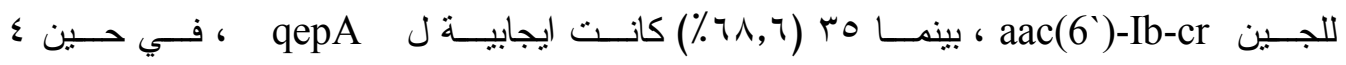
(\% ₹,^) تز ايد في السنوات العشرين الماضية ولكن للأسف لا بيانات كافية حول المعزلات و ومدي إحتو اءهـا علي الجينات المحملة علي البلازميد و القابلة للإنتقال بين أفر اد الميكروب الواحد أو بين اجيال هذا الميكروب أو إلي ميكروبات أخري قد تكون أكثر خطورة في إصابتها سواء في مجـال الدواجن أو الإنسان. مطلوب مزيد من البحث بشأن مشكلة مقاومة الميكروبات لمضـادات الحيويـة سـواء علي لي المستوي البيطري أو البشري في مصر ويوصى ببرنامج لمسح وتعقب هذه المشكلة علي مسنوي القطر المصري.

الكلمات الدالة : المقاومة البكتيرية للفلوروكينولون' الدو اجن ، الميكروب القولوني ، جينـات qnrA, qnrB, qnrS, aac(6')-Ib-cr, and qepA المقاومة المحملة علي البلازميد 